\title{
Oxetanes from the Ring Contraction of $\alpha$-Triflates of $\gamma$-Lactones: Oxetane Nucleosides and Oxetane Amino Acids
}

\author{
Sarah F. Jenkinson and George W. J. Fleet ${ }^{\star}$
}

\begin{abstract}
Triflates of $\gamma$-lactones with potassium carbonate in methanol give efficient contraction of the ring to oxetane-1-carboxylates in which the oxygen substituent at $\mathrm{C}(3)$ of the oxetane is predominantly trans to the carboxylate at $\mathrm{C}(2)$, regardless of the stereochemistry of the starting triflate. The limitations of the procedure are discussed and compared with analogous reactions for the preparation of THF carboxylates. The potential of the contraction in the preparation of oxetane nucleosides (such as oxetanocin) and oxetane sugar amino acids (analogues of oxetin) as peptidomimetics with predisposition to form secondary structural motifs is illustrated.
\end{abstract}

Keywords: Lactones $\cdot$ Nucleoside $\cdot$ Oxetane $\cdot$ Oxetanocin $\cdot$ Oxetin $\cdot$ Ring contraction $\cdot$ Sugar amino acid

\section{Ring Contraction of $\alpha$-Triflates of $\gamma$-Lactones to Oxetanes}

Acidic or basic methanol treatment of $\alpha$ triflates of $\gamma$-lactones ${ }^{[1]}$ with a free hydroxyl group at $\mathrm{C}(5)$ provides a general and high yielding synthesis of highly substituted and homochiral THF carboxylates in which the ring closure occurs with exclusive inversion of configuration at $\mathrm{C}(2)$ (Scheme 1). ${ }^{[2]}$ Thus the lactone triflate $1 \alpha$ undergoes ring opening by methanol/methoxide to form an open chain triflate $2 \alpha$ which undergoes attack by the $\mathrm{C}(5)$-hydroxyl group to give a clean $\mathrm{S}_{\mathrm{N}} 2$ reaction to give $3 \alpha$ only arising from inversion of configuration at $\mathrm{C}(2)$. Although both $\mathrm{C}(4)$ - and $\mathrm{C}(5)-\mathrm{OH}$ groups are free in the open chain triflate $2 \alpha$, only the THF ring is formed; there is no oxetane formation by attack from the $\mathrm{C}(4)-\mathrm{OH}$ group. ${ }^{[3]}$ The epimeric triflate $\mathbf{1} \beta$ proceeds in the same stereospecific manner to give exclusively the epimer $3 \beta$. Similarly six-membered

\footnotetext{
*Correspondence: Dr. G. W. J. Fleet Chemistry Research Laboratory

Department of Chemistry

University of Oxford

Mansfield Road

Oxford, OX1 3TA, UK

E-mail: george.fleet@chem.ox.ac.uk
}

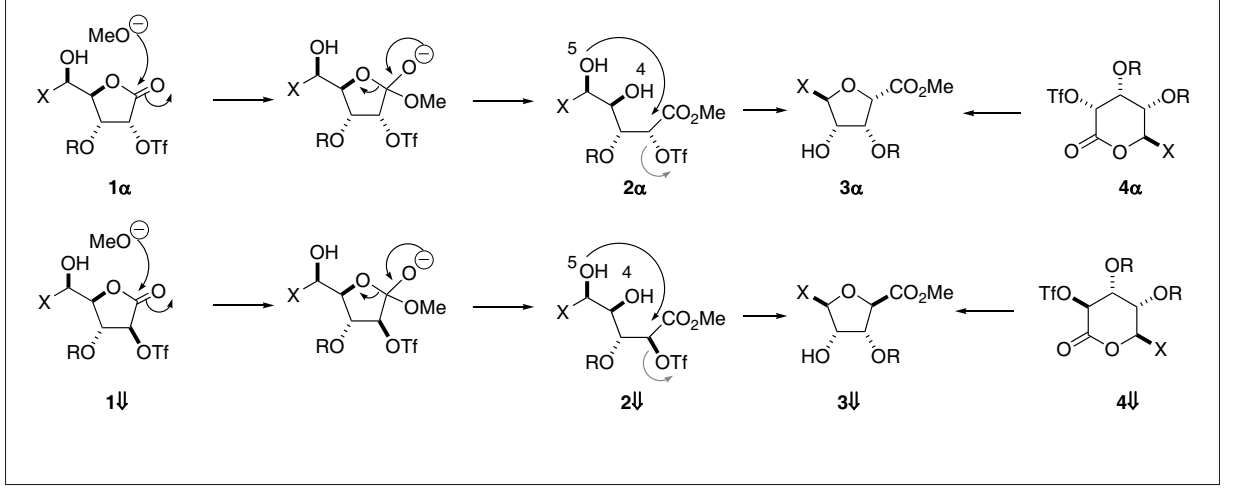

Scheme 1. Formation of THF by acid- or base-catalyzed ring contraction of lactone triflates.

rings are formed in favor of oxetanes. ${ }^{[4]}$ The epimeric $\alpha$-triflates of $\delta$-lactones $4 \alpha$ and $\mathbf{4} \beta$ also give stereospecific conversion to the THF carboxylates $\mathbf{3} \alpha$ and $\mathbf{3} \beta$, respectively. ${ }^{[5]}$

In contrast, fully protected $\alpha$-triflates of $\gamma$-lactones with basic methanol give oxetane carboxylates. ${ }^{[6-12]}$ Investigation of the stereochemical outcome of such ring contraction reactions revealed that the predominant, and sometimes exclusive, isomer formed had the carboxylate and the $\mathrm{C}(3)$-oxygen substituent trans to each other, regardless of the stereochemistry of the initial triflate (Scheme 2). Thus treatment of either of the epimeric lactones $\mathbf{5} \alpha$ or $\mathbf{5} \beta$ with potassium carbonate in methanol produced the same oxetane $7 \beta$ as the major product; only a minor - but different - amount of $7 \alpha$ was formed. Equilibration experiments indicated that the product esters 7 were configurationally stable to the reaction conditions. The $\mathrm{S}_{\mathrm{N}} 2$ closure of the open chain triflates 6 to produce the oxetane ring 7 is particularly difficult with a $\beta$-oxygen substituent. Thus, epimerization of $6 \alpha$ to $6 \beta$ (with closure to the oxetane $7 \beta$ ) is faster than the $S_{N} 2$ formation of the oxetane with the steric hindrance of adjacent cis-substituents. For example, the epimeric triflates $\mathbf{8} \beta$ and $\mathbf{8} \alpha$ both give $\mathbf{9} \alpha$ as the major product with minor - but differing - amounts of the all cis-substituted oxetane $9 \beta$ (Scheme 3). ${ }^{[7]}$

Similar ring contractions were observed for all four of the diastereomeric 3,5-di-O-benzyl-2- $O$-triflate pentonolactones; ${ }^{[8]}$ all the carboxylates were found to have the $\mathrm{C}(2)$ and $\mathrm{C}(3)$ substituents on the oxetane ring trans to each other (Scheme 4). In contrast to these findings, ring contractions of $\gamma$-lactones without oxygen substituents at $\mathrm{C}(3)$ were found to proceed with a clean inversion of configuration at $\mathrm{C}(2)$ of the sugar lactone; the lack of a $\beta$ oxygen substituent may make the $\mathrm{S}_{\mathrm{N}} 2$ ring closure easier and competes with epimerization of the open chain triflates. ${ }^{[9]}$

3-Azido- $\mathbf{1 0}$ and 3-fluoro- $\mathbf{1 2} \alpha$-triflates of $\gamma$-lactones with potassium carbonate in methanol do not give the corresponding azido- 14 and fluoro- 15 substituted ox- 


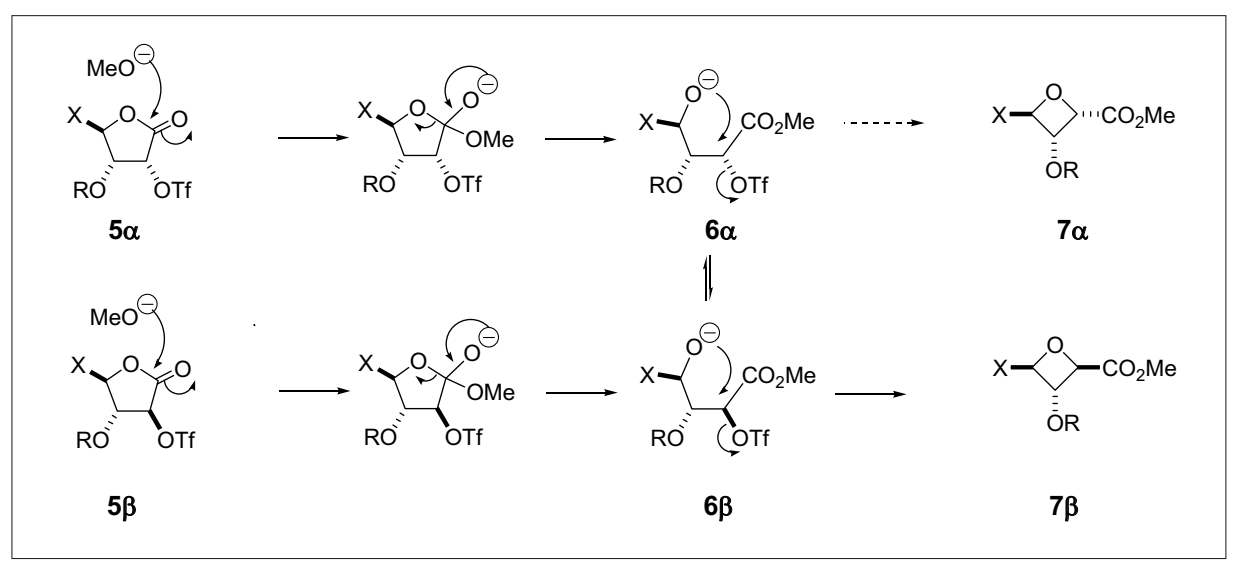

Scheme 2. Formation of oxetanes by ring contraction of $\gamma$-lactone triflates.

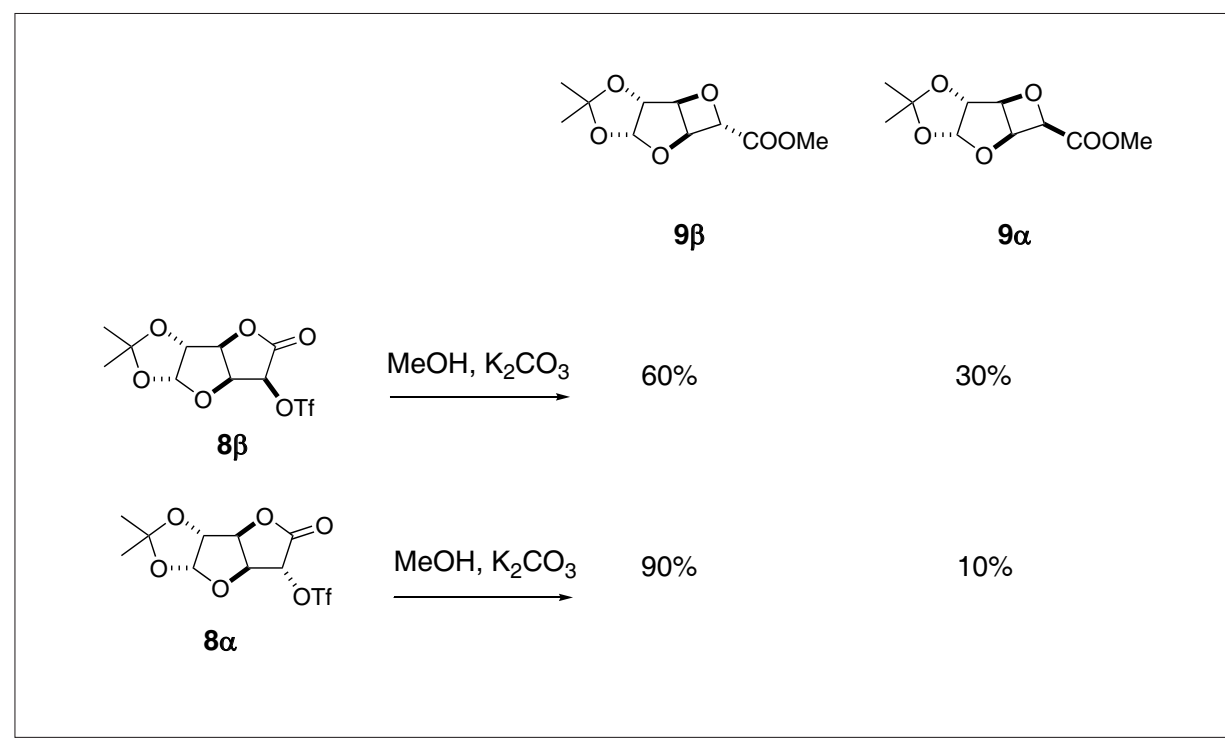

Scheme 3. Oxetane formation from ring-fused lactones.

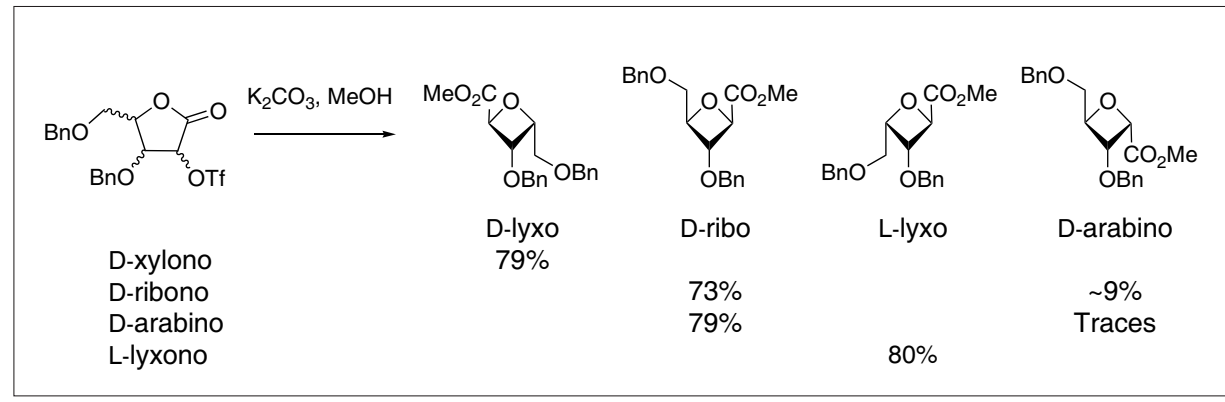

Scheme 4. Ring contractions of di-O-benzyl- $\alpha$-triflates of $\gamma$-lactones.

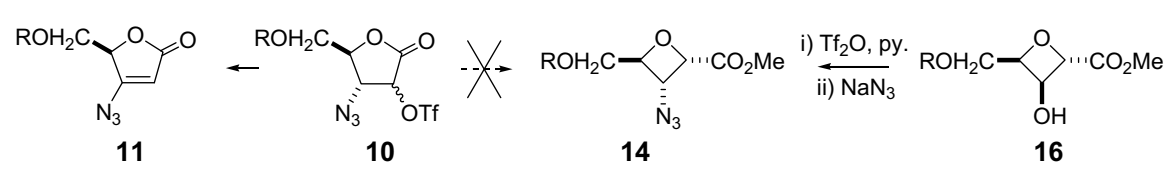

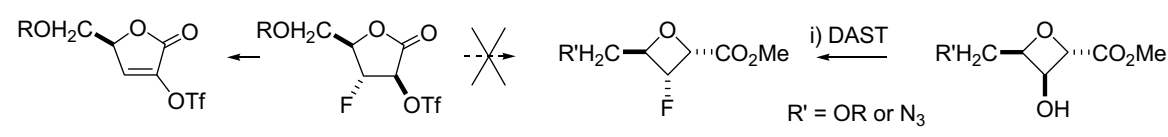

$$
\begin{aligned}
& 13 \\
& 12 \\
& 15 \\
& 17
\end{aligned}
$$

Scheme 5. C(3)-substituted fluoro- and azido-oxetanes. etanes; competing elimination reactions ${ }^{[10]}$ cause loss of triflic acid from the azido triflate $\mathbf{1 0}$ to form the azide 11, whereas the fluoro lactone $\mathbf{1 2}$ loses HF to form the vinyl triflate 13 (Scheme 5). However, the azido- 14 and fluoro- 15 oxetanes may be accessed by nucleophilic displacement reactions on the oxetane ring of $\mathbf{1 6}$ and $\mathbf{1 7}$, respectively. ${ }^{[11-13]}$ It is remarkable that the $\beta$-triflate undergoes a clean high yield $\mathrm{S}_{\mathrm{N}} 2$ reaction; presumably the elimination reaction to introduce two $\mathrm{sp}^{2}$ carbons in the oxetane ring would induce too much strain.

3-Hydroxy oxetane carboxylates are prone to base-catalyzed retro-aldol ring opening. Thus, reaction of the benzoate $\mathbf{1 8}$ with basic methanol results in the formation of retro-aldol product $\mathbf{2 0}$ (Scheme 6) since the initially formed $\beta$-hydroxy ester $\mathbf{1 9}$ can readily fragment. Hydrolysis of $\mathbf{1 8}$ with hydroxide in aqueous THF - with hydrolysis of the more reactive methyl ester to the carboxylate salt - gives an intermediate 21 which can no longer undergo the retro-aldol reaction. ${ }^{66,14,15]}$

A change in the stereochemistry of an oxetane ring cis-fused to a benzylidene ring may cause a change in the conformational/configurational preference of the molecule. The rhamnose-derived lactone triflate $\mathbf{2 2}$ affords $\mathbf{2 3}$ in which the formation of the oxetane occurs with overall retention of configuration at $\mathrm{C}(2)$ of the sugar moiety. The epimeric triflate $\mathbf{2 5}$ changed the stereochemistry at the benzylidene position on silica to form the triflate $\mathbf{2 6}$. Thus treatment of the mixture of $\mathbf{2 5}$ and $\mathbf{2 6}$ with potassium carbonate in methanol produced the epimeric benzylidene oxetanes $\mathbf{2 3}$ and 27 , both of which on hydrolysis gave the same oxetane 24 (Scheme 7). [16]

\section{Oxetane Nucleosides}

Oxetane carboxylates can be transformed by the Barton modification of the Hunsdiecker reaction ${ }^{[17]}$ to stable chlorooxetanes; thus $\mathbf{9}$ may be converted to $\mathbf{2 8}$ (Scheme 8). Chlorooxetanes are much more stable - particularly with a $\beta$-oxygen substituent in the oxetane ring - than their furanoside analogues, as $\mathrm{S}_{\mathrm{N}} 1$ loss of chloride to produce an $\mathrm{sp}^{2}$ carbon in a four-membered ring is unfavorable. ${ }^{[18]}$ Reaction of the stable chlorooxetane $\mathbf{2 8}$ with a nucleoside base, such as adenine, gives an entry to oxetane nucleosides 29 (Scheme 8). [19]

Two oxetane nucleosides have been isolated as natural products. Albucidin 30, ${ }^{[20]}$ a novel herbicide from the culture broth of Streptomyces albus, has an activity against HIV approximately 10 -fold that of oxetanocin A (31), isolated from $\mathrm{Ba}$ cillus megaterium. ${ }^{[21]}$ Oxetanocin $\mathbf{3 1}$ was prepared (Scheme 9) from the lactone triflate 34, itself derived from diacetone glu- 

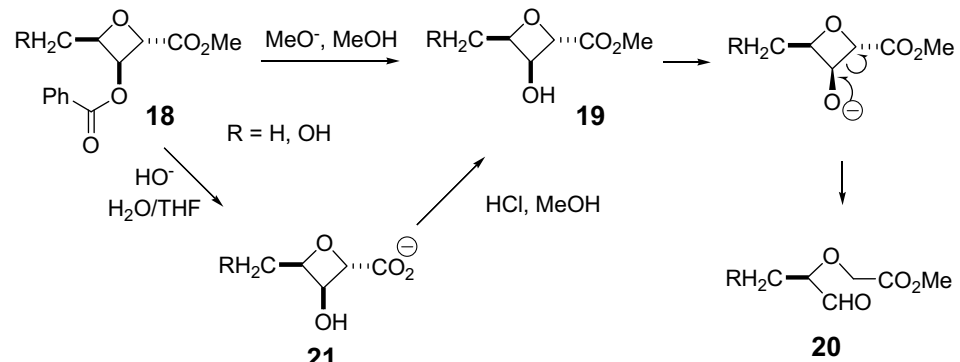

20

Scheme 6. Retro-aldol condensation of 3-hydroxy oxetane carboxylates.

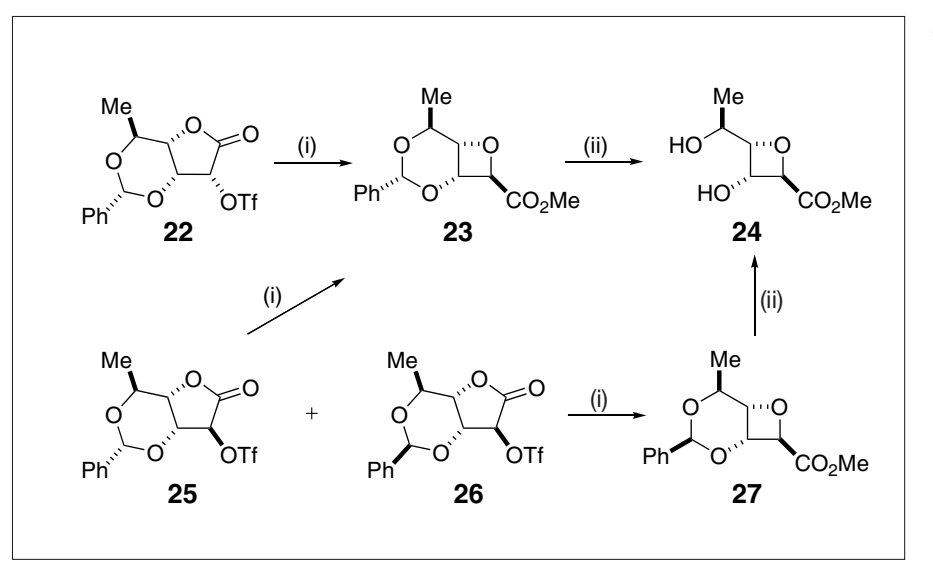

Scheme 7. (i) $\mathrm{K}_{2} \mathrm{CO}_{3}$, $\mathrm{MeOH}$; (ii) $\mathrm{HCl}, \mathrm{MeOH}$

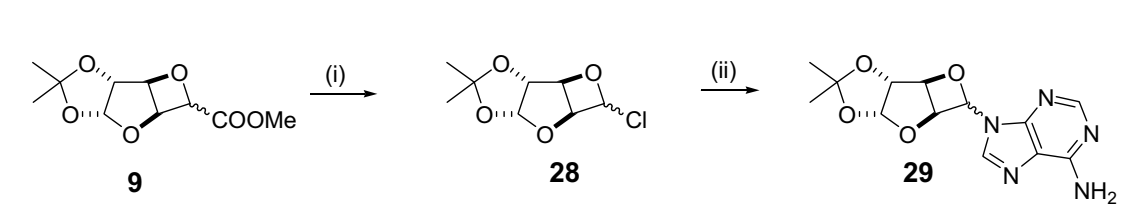

Scheme 8. (i) aq. $\mathrm{NaOH}$; then $(\mathrm{COCl})_{2}$; then $\mathrm{N}$-hydroxypyridine-2-thione, $\mathrm{CCl}_{4}$ (ii) adenine, $\mathrm{K}_{2} \mathrm{CO}_{3}$, 18-crown-6, MeCN / DMF (1:1).

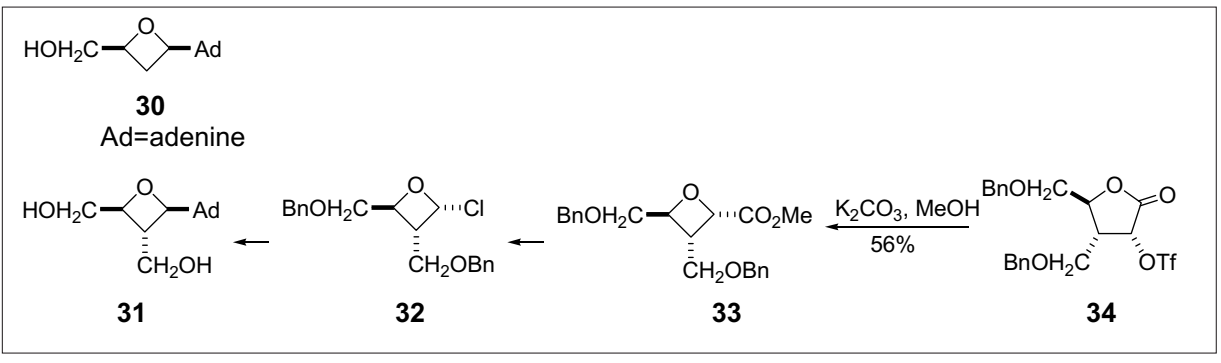

Scheme 9. Synthesis of oxetanocin.<smiles>CCOC(=O)OC1C(=O)OC(COc2ccccc2)C1[O]</smiles>

35<smiles>OCC1OC(O)C1O</smiles>

38

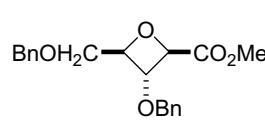

36

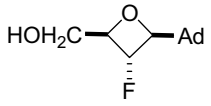

39

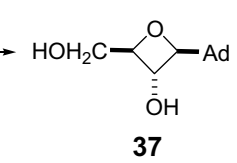

$\mathrm{HOH}_{2} \mathrm{C} \underset{\overline{\overline{\mathrm{N}}}_{3}}{\mathrm{O}_{40}}{ }^{\mathrm{Ad}}$

40
Scheme 10. Oxetane nucleosides. cose. ${ }^{[22]}$ Lactone 34, with a carbon - rather than an oxygen - substituent at C(3), underwent ring contraction to the oxetane with inversion to give $\mathbf{3 3}$ in which the carboxylate is $c i s$ to the adjacent hydroxymethyl substituent. Subsequent conversion to the chloride $\mathbf{3 2}$ (less stable since there is no $\beta$-oxygen), followed by treatment with adenine, afforded oxetanocin 31.

Ring contraction of either of the epimeric triflates $\mathbf{3 5}$ gave $\mathbf{3 6}$ as a key intermediate in the synthesis of oxetanocin analogues, including noroxetanocin 37, epinoroxetanocin 38, and the fluoro $\mathbf{3 9}$ and azido 40 oxetane nucleosides; epinoroxetanocin 38 was more active against HIV than oxetanocin itself (Scheme 10). [23]

\section{Oxetane Amino Acids}

Sugar amino acids (SAA) have provided a family of peptidomimetic scaffolds ${ }^{[24]}$ with the propensity to induce secondary structural motifs and with the potential of adjusting properties of the oligopeptides such as solubility and stability to peptide cleavage. The four-membered oxetane rings, being conformationally less flexible than their furanose and pyranose counterparts, provide a class of foldamers with access to a wide range of novel secondary structures. The ring contraction reaction generates oxetane carboxylates which allow conversion to $\alpha, \beta$ and $\delta$ oxetane amino acid scaffolds.

\subsection{Oxetane $\alpha$-Amino Acids}

Bromination at the $\alpha$-position of furanose carboxylates to form $\alpha$-bromoesters, followed by reaction with sodium azide, gives $\alpha$-azido carboxylates, ${ }^{[25]}$ which can act as $\alpha, \alpha$-disubstituted THF $\alpha$-amino acid scaffolds. ${ }^{[26]}$ Similar methodology may be applied to oxetanes; thus, reaction of either of the epimers 9 with LiHMDS followed by $\mathrm{CBr}_{4}$ gave a separable mixture of the bromides 41 and $\mathbf{4 2}$. Both $\alpha$-bromoesters 41 and 42 readily underwent displacement with azide with complete inversion of configuration to generate the esters 43 and 44 respectively as oxetane $\alpha$-amino acid scaffolds (Scheme 11).[27]

\subsection{Oxetane $\beta$-Amino Acids}

Oxetin $\mathbf{4 5}^{[28]}$ is a naturally occurring antibiotic comprising a cis- $\beta$-amino acid containing an oxetane ring. Its three stereoisomers do not exhibit antibacterial activity. ${ }^{[29]} \beta$-Amino acids are among the most successful families of foldamers, and induce secondary structure - particularly helical motifs - in much shorter sequences than those of $\alpha$-amino acids. ${ }^{[30]}$ A series of oxetane $\beta$-amino acid scaffolds have been prepared as analogues of oxetin $\mathbf{4 5}$ and as potential foldamers. Several differ- 
ently protected cis and trans- $\beta$-amino acid oligomers have been synthesized from the corresponding $\beta$-azido ester monomer units; the key steps in the syntheses are the efficient and high yield $\mathrm{S}_{\mathrm{N}} 2$ reactions on triflates $\beta$ to the carboxylates. ${ }^{311}$ The benzylidene triflate 46 , readily available from D-xylose, gives efficient ring contraction to the protected oxetane $\mathbf{4 7}$ which may be converted to a number of derivatives $\mathbf{4 8}$ with only the secondary $\mathrm{OH}$ at $\mathrm{C}(3)$ unprotected (Scheme 12). Esterification of 48 by triflic anhydride, followed by $\mathrm{S}_{\mathrm{N}} 2 \mathrm{re}$ action with cesium trifluoroacetate, gives the epimeric alcohol 49 in over $90 \%$ yield. $\mathrm{S}_{\mathrm{N}} 2$ displacement of the triflates of $\mathbf{4 8}$ and 49 with sodium azide gives high yields of the inverted azides $\mathbf{5 0}$ and $\mathbf{5 1}$, respectively. Such azidoesters are ideal intermediates for incorporation of such $\beta$-amino acids into oligopeptides.

Homooligomers from cis- $\beta$-amino acids were found to adopt helical conformations in solution stabilized by tenmembered ring hydrogen bonds, with those derived from D-xylose adopting a right-handed - and those from L-rhamnose a left-handed - helical structure. The transoligomers in contrast formed extended structures in solution stabilized by weak hydrogen bonds.

\subsection{Oxetane $\delta$-Amino Acids}

Oxetane $\delta$-amino acids - like their THF and tetrahydropyran congeners - may be viewed as dipeptide isosteres. The side chain azide can be introduced before or after the ring contraction of the lactone. The value of the Hanessian reaction ${ }^{[32]}$ for introduction of the azide after formation of the oxetane is illustrated in the synthesis of 2,4-trans $\delta$-azido ester monomer units (Scheme 13). The benzylidene oxetanes 47 (from D-xylose) and 27 (from L-rhamnose) react with $N$-bromosuccinimide (NBS) to give the bromides $\mathbf{5 2}$ and $\mathbf{5 4}$ respectively; the bromides can readily be manipulated to give the corresponding azides $\mathbf{5 3}$ and 55. [33]

For 2,4-cis $\delta$-azido ester monomers, introduction of the azide prior to oxetane formation is generally preferable in order to avoid intermediates that can undergo reverse aldol reactions (Scheme 14). Thus the triflates $\mathbf{5 6}$ (from L-arabinose) and $\mathbf{5 7}$ (from L-xylose) afford the oxetanes $\mathbf{5 8}$ and 59, respectively. ${ }^{[6,13-15]}$

The 2,4-cis-oxetane $\delta$-amino acid scaffold derived from $\mathbf{5 8}$ formed a repeating $\beta$-turn type structure, whereas oligomers of the 2,4-trans-oxetane $\delta$-amino acid scaffolds derived from $\mathbf{5 3}$ and $\mathbf{5 5}$ did not adopt well-defined secondary structures stabilized by hydrogen bonding. ${ }^{[34]}$ A cyclic tetramer $\mathbf{6 1}$ is formed by hydrogenation of a linear azido-pentafluorophenyl ester tetramer 60 at high dilution (Scheme 15). ${ }^{[35]}$

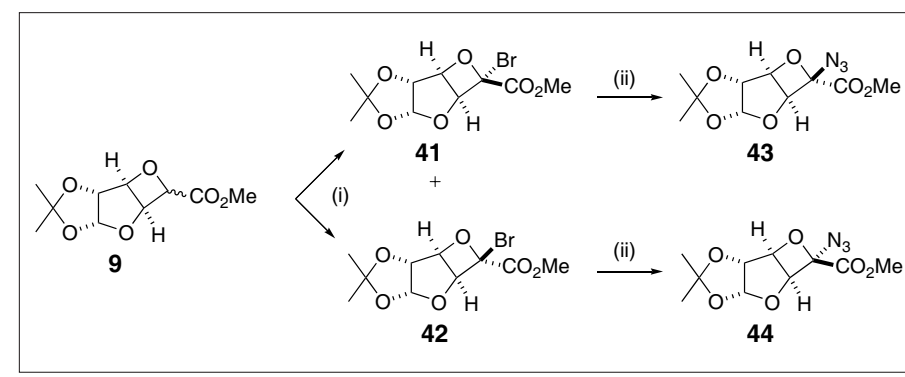

Scheme 11. (i) LiHMDS, THF, $-78^{\circ} \mathrm{C}$; then $\mathrm{CBr}_{4}$ (ii) $\mathrm{NaN}_{3}$, DMF, RT.

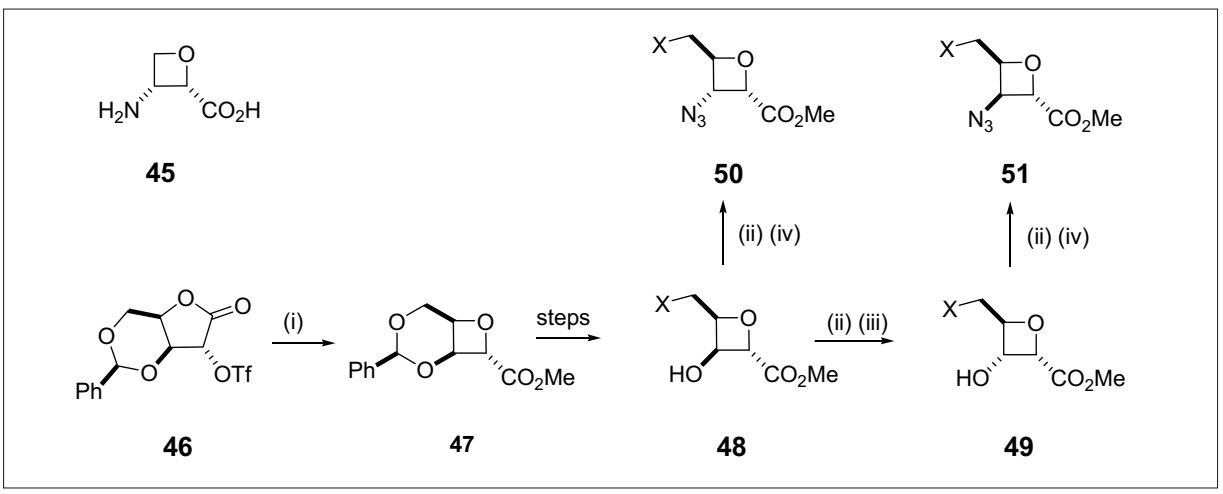

Scheme 12. (i) $\mathrm{K}_{2} \mathrm{CO}_{3} \mathrm{MeOH}$ (ii) $\mathrm{Tf}_{2} \mathrm{O}$, pyridine, $\mathrm{CH}_{2} \mathrm{Cl}_{2}-30$ to $-20^{\circ} \mathrm{C}$ (iii) $\mathrm{CsOCOCF}_{3}$, MeCOEt (iv) $\mathrm{NaN}_{3}, \mathrm{DMF}$.

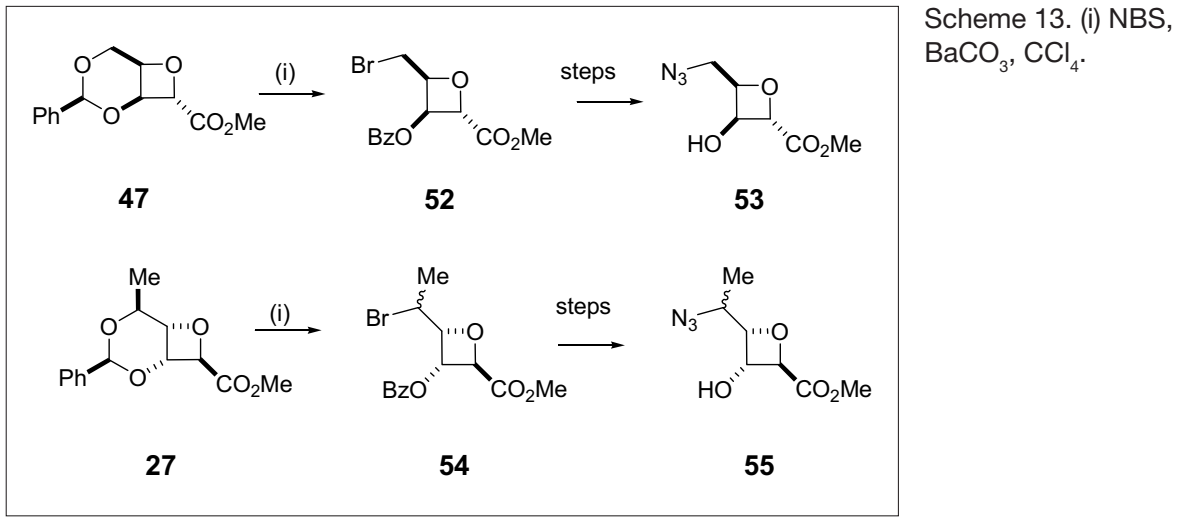

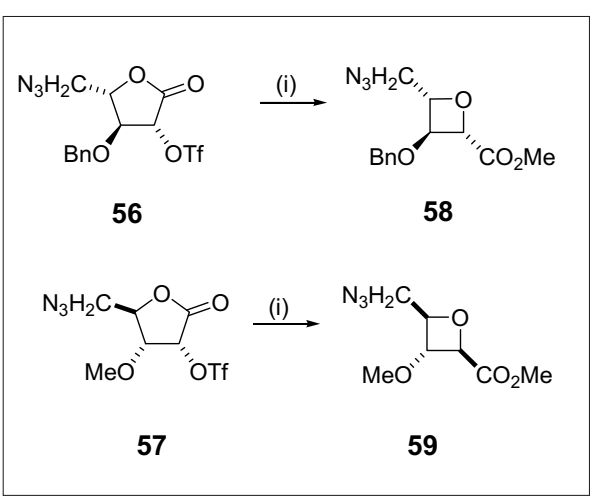

Scheme 14. (i) $\mathrm{K}_{2} \mathrm{CO}_{3}$, $\mathrm{MeOH}$.

\section{Summary}

Oxetane carboxylic acids can be readily synthesized by the ring contraction of $\alpha$-triflates of $\gamma$-lactones with basic methanol, provided that the oxygen substituent at $\mathrm{C}(3)$ is trans to the carboxylate. This method has been applied to the synthesis of oxetane nucleosides and a range of oxetane sugar amino acid scaffolds with a predisposition towards the formation of secondary structural features in small oligomers.

Received: September 15, 2010

[1] J. R. Wheatley, C. J. F. Bichard, S. J. Mantell, J. C. Son, D. J. Hughes, G. W. J. Fleet, D. Brown, J.Chem. Soc., Chem. Commun. 1993, 1065.

[2] a) A. A. Edwards, G. J. Sanjayan, S. Hachisu, R. Soengas, A. Stewart, G. E. Tranter, G. W. J. Fleet, Tetrahedron 2006, 62, 4110; b) G. J. Sanjayan, A. Stewart, S. Hachisu, R. Gonzalez, M. P. Watterson, G. W. J. Fleet, Tetrahedron Lett. 2003, 44, 5847; c) M. P. Watterson, A. A. Edwards, J. A. Leach, M. D. Smith, O. Ichihara, G. W. J. Fleet, Tetrahedron Lett. 2003, 44, 5853.

[3] R. Csuk, E. Prell, Tetrahedron 2010, 66, 1313.

[4] a) J. C. Estevez, A. J. Fairbanks, G. W. J. Fleet, Tetrahedron 1998, 54, 13591; b) K. Y. Hsia, P. Ward, G. W. J. Fleet, Tetrahedron Lett. 1994, 35,3361 .

[5] S. S. Choi, P. M. Myerscough, A. J. Fairbanks, B. M. Skead, C. J. F. Bichard, S. J. Mantell, G. W. J. Fleet, J. Saunders, D. Brown, J. Chem. Soc., Chem. Commun. 1992, 1605.

[6] B. Lopez-Ortega, S. F. Jenkinson, T. D. W Claridge, G. W. J. Fleet, Tetrahedron: Asymm. 2008, 19, 976. 


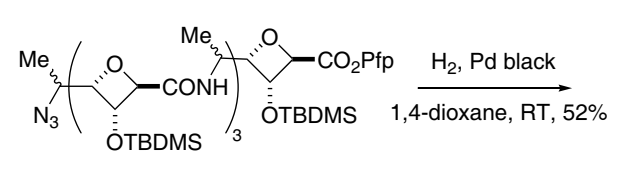

60

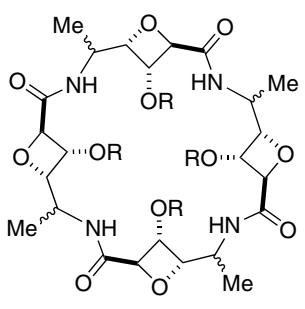

61

Scheme 15. Formation of cyclic tetramer.

[7] G. N. Austin, G. W. J. Fleet, J. M. Peach, K. Prout, J. C. Son, Tetrahedron Lett. 1987, 28, 4741.

[8] D. R. Witty, G. W. J. Fleet, K. Vogt, F. X Wilson, Y. Wang, R. Storer, P. L. Myers, C. J. Wallis, Tetrahedron Lett. 1990, 31, 4787.

[9] D. R. Witty, G. W. J. Fleet, S. Choi, K. Vogt, F. X. Wilson, Y. Wang, R. Storer, P. L. Myers, C. J. Wallis, Tetrahedron Lett. 1990, 31, 6927.

[10] R. P. Elliott, G. W. J. Fleet, K. Vogt, F. X. Wilson, Y. Wang, D. R. Witty, R. Storer, P. L. Myers, C. J. Wallis, Tetrahedron: Asymm. 1990, 1, 715.

[11] Y. Wang, G. W. J. Fleet, F. X. Wilson, R. Storer, P. L. Myers, C. J. Wallis, O. Doherty, D. J. Watkin, K. Vogt, D. R. Witty, J. M. Peach, Tetrahedron Lett. 1991, 32, 1675.

[12] S. F. Barker, D. Angus, C. Taillefumier, M. R. Probert, D. J. Watkin, M. P. Watterson, T. D. W Claridge, G. W. J. Fleet, Tetrahedron Lett. 2001 , 42, 4247.

[13] S. D. Lucas, A. P. Rauter, J. Schneider, H. P. Wessel, J. Carbohydr. Chem. 2009, 28, 431

[14] a) S. D. Lucas, A. P. Rauter, H. P. Wessel, J Carbohydr. Chem. 2008, 27, 172; b) S. D. Lucas, H. Iding, A. Alker, H. P. Wessel, A. P. Rauter, J. Carbohydr. Chem. 2006, 25,187.

[15] S. F. Jenkinson (née Barker), T. Harris, G. W. J. Fleet, Tetrahedron: Asymm. 2004, 15, 2667.

[16] S. W. Johnson, D. Angus, C. Taillefumier, J. H. Jones, D. J. Watkin, E. Floyd, J. G. Buchanan, G. W. J. Fleet, Tetrahedron: Asymm. 2000, 11, 4113.

[17] D. H. R. Barton, D. Crich, W. B. Motherwell, Tetrahedron 1985, 41, 3901 .
[18] G. W. J. Fleet, J. C. Son, J. M. Peach, T. A. Hamor, Tetrahedron Lett. 1988, 29, 1449.

[19] G. W. J. Fleet, J. C. Son, K. Vogt, J. M. Peach, T. A. Hamor, Tetrahedron Lett. 1988, 29, 1451.

[20] a) D. R. Hahn, P. R. Graupner, E. Chapin, J. Gray, D. Heim, J. R. Gilbert, B. C. Gerwick, J. Antibiot. 2009, 62, 191; b) M. Kitagawa, S. Hasegawa, S. Saito, N. Shimada, T. Takita, Tetrahedron Lett. 1991, 32, 3531.

[21] a) N. Shimada, S. Hasegawa, T. Harada, T. Tomisawa, A. Fujii, T. Takita, J. Antibiot. 1986, 39, 1623; b) A. Rustullet, R. Alibes, P. de March, M. Figueredo, J. Font, Org. Lett. 2007, $15,2827$.

[22] F. X. Wilson, G. W. J. Fleet, K. Vogt, Y. Wang, D. R. Witty, R. Storer, P. L. Myers, C. J. Wallis, Tetrahedron Lett. 1990, 31, 6931.

[23] a) F. X. Wilson, G. W. J. Fleet, D. R. Witty, K. Vogt, Y. Wang, R. Storer, P. L. Myers, C. J. Wallis, Tetrahedron: Asymm. 1990, 1, 525; b) Y. Wang, G. W. J. Fleet, R. Storer, P. L. Myers, C. J. Wallis, O. Doherty, D. J. Watkin, K. Vogt, D. R. Witty, F. X. Wilson, J. M. Peach, Tetrahedron: Asymm. 1997, 8, 527.

[24] a) M. D. P. Risseeuw, M. Overhand, G. W. J. Fleet, M. I. Simone, Tetrahedron: Asymm. 2007, 18, 2001; b) M. D. Smith, G. W. J. Fleet, J. Peptide Sci. 1999, 5, 425; c) A. A. Edwards, G. W. J. Fleet, G. E. Tranter, Chirality 2006, 18 , 265.

[25] a) A. J. Fairbanks, G. W. J. Fleet, Tetrahedron 1995, 51, 3881; b) A. J. Fairbanks, P. S. Ford, D. J. Watkin, G. W. J. Fleet, Tetrahedron Lett. 1993, 34, 3327 .
[26] a) J. C. Estevez, M. D. Smith, M. R. Wormald, G. S. Besra, P. J. Brennan, R. J. Nash, G. W. J. Fleet, Tetrahedron Asymm. 1996, 7, 391; b) J. C. Estevez, M. D. Smith, A. L. Lane, S. Crook, D. J. Watkin, G. S. Besra, P. J. Brennan, R. J. Nash, G. W. J. Fleet, Tetrahedron Asymm. 1996, 7, 387

[27] S. Choi, D. R. Witty, G. W. J. Fleet, P. L. Myers, R. Storer, C. J. Wallis, D. Watkin, L. Pearce, Tetrahedron Lett. 1991, 32, 3569.

[28] a) S. Omura, M. Murata, N. Imamura, Y. Iwai, H. Tanaka, J. Antibiot. 1984, 31, 1324; b) M. L. Blauvelt, A. R. Howell, J. Org. Chem. 2008, 73, 517.

[29] Y. Kawahata, S. Takatsuto, N. Ikekawa, M Murata, S. Omura, Chem. Pharm. Bull. 1986, 34,3102 .

[30] a) R. Threlfall, A. Davies, N. M. Howarth, J. Fisher, R. Cosstick, Chem. Commun. 2008, 585; b) D. Seebach, A. K. Beck, D. J. Bierbaum, Chem. Biodiversity 2004, 1, 1111; c) F. Sussman, M. C. Villaverde, J. C. Estevez, R. J. Estevez, J. Phys., Chem. B 2009, 113, 9669; d) Y. D. Wu, W. Han, D. P. Wang, Y. Gao, Y. L. Zhao, Accts. Chem. Res. 2008, 41, 1418; e) P. Schramm, G. V. M. Sharma, H. J. Hofmann, Biopolymers 2010, 94, 279.

[31] T. D. W. Claridge, J. M. Goodman, A. Moreno, D. Angus, S. F. Barker, C. Taillefumier, M. P. Watterson, G. W. J. Fleet, Tetrahedron Lett. 2001, 42, 4251.

[32] S. Hanessian, Adv. Chem. Ser. 1968, 74, 159.

[33] a) S. W. Johnson, S. F. Jenkinson (née Barker), D. Angus, I. Perez-Victoria, T. D. W. Claridge, G. W. J. Fleet, J. H. Jones, J. Peptide Sci. 2005 11, 303; b) S. W. Johnson, S. F. Jenkinson (née Barker), J. H. Jones, D. J. Watkin, G. W. J. Fleet, Tetrahedron: Asymm. 2004, 15, 3263 ; c) D. J. Watkin, S. W. Johnson, J. H. Jones, G. W. J. Fleet, Acta Cryst. 2004 E60, o1609; d) S. W. Johnson, S. F. Jenkinson (née Barker), D Angus, C. Taillefumier, J. H. Jones, G. W. J. Fleet, Tetrahedron: Asymm. 2004, 15, 2681.

[34] T. D. W. Claridge, B. Lopez-Ortega, S. F. Jenkinson, G. W. J. Fleet, Tetrahedron: Asymm. 2008, 19, 984 .

[35] S. W. Johnson, G. W. J. Fleet, J. H. Jones, J. Peptide Sci. 2006, 12, 559. 